\title{
Agronomic and Genetic Analysis of Performance of Guar Varieties under Rainfed Conditions in a Semi-Arid Climate on Alfisols
}

\author{
A.V. Ramanjaneyulu ${ }^{1 *}$, A. Madhavi ${ }^{2}$, M. Venkata Ramana ${ }^{1}$, T.L. Neelima ${ }^{1}$, \\ K. Indudhar Reddy ${ }^{1}$, A. Srinivas ${ }^{3}$, G. Anuradha ${ }^{1}$ and C.V. Sameer Kumar ${ }^{1}$ \\ ${ }^{1}$ Regional Agricultural Research Station, Palem 509 215, Telangana state, India \\ ${ }^{2}$ Soil Test Crop Response Scheme, Professor Jayashankar Telangana State Agricultural \\ University, Telangana state, India \\ ${ }^{3}$ Main farm, Agricultural Research Institute, Rajendranagar 500 030, Professor Jayashankar \\ Telangana State Agricultural University, Telangana state, India \\ *Corresponding author
}

\section{A B S T R A C T}

\section{Keywords}

Agronomic and genetic superiority, Guar,

Powdery mildew, Semiarid climate, Varieties

Article Info

Accepted:

15 July 2018

Available Online:

10 August 2018
Guar is known for its drought hardiness and preferred for extraction of galactomannan gum. Its adaptability is proved in Mediterranean and sub-tropical environments. Information on its adaptability in semi-arid environments is limited. Hence, we evaluated six released varieties of guar (HG-365, HG-563, RGC-936, RGC-1002, RGC-1035 and RGC-1066) under rainfed conditions during kharif 2013 and 2014 with a view to identify agronomically and genetically superior ones. Among the varieties tested, RGC-936 produced significantly higher no. of branches and clusters thus seed yield $\left(0.92 \mathrm{tha}^{-1}\right)$. The seed yield was $87.8 \%, 44.0 \%, 35.7 \%, 26.5$ and $24.5 \%$ higher than that of RGC-1066, RGC-1002, HG-563 and HG-365, respectively. Besides, higher gross and net returns (Rs. 46,508 and 31,758 $\mathrm{ha}^{-1}$ ) and $\mathrm{B}$ : C ratio ((3.15) were also accrued due to RGC-936 variety. Genetic analysis showed that plants with short height, more no. of branches, clusters and pod plant ${ }^{-1}$ are the important traits to be given priority to develop high yielding cultivars, as they influenced economic yield positively and significantly.

\section{Introduction}

Guar [Cyamopsis tetragonoloba L. (Taub)] is commonly known as clusterbean. It is best adapted to tropical and subtropical regions. Due to high drought and salinity tolerance (Francois et al., 1990; Ashraf et al., 2005), guar could be a valuable alternative crop for the exploitation of the semiarid environments (Losavio et al., 1995), where high temperature, poor erratic rainfall and elevated water and salt content do not allow the cultivation of many crops. Being a legume, it has good capability to fix atmospheric nitrogen (Elsheikh and Ibrahim, 1999). It is the potential vegetable cum industrial crop grown for its tender pods for vegetable and for endosperm gum i.e. galactomannan (22-33\%) (Gresta et al., 2013) and for guar meal (Singh et al., 2014). This endosperm gum is used in textile, paper, pharmaceutical, neutraceutical, cosmaseutical and petroleum industries. It is 
grown primarily for gum purpose. India ranks first among the guar producing countries and contributes around $80 \%$ share of the worlds' total production. Though the crop is popular in Mediterranean and sub-tropical regions of the world, its spread is less in semi-arid environments. Hence, efforts are on to introduce guar crop in semi-arid tropical (SAT) climate under rainfed conditions especially for galactomannan purpose (Ramanjaneyulu et al., 2016). Though, this crop is photosensitive and highly sensitive to winter temperatures, the climatic conditions in semi tropical climate are favourable to the crop, thus, it can be grown throughout the year. While introducing a crop and testing its suitability, identification of high yielding variety is utmost important. In view of this fact, we felt it was important evaluate few released guar varieties agronomically and genetically and identify suitable ones for rainfed conditions under semi-arid climate on Alfisols.

\section{Materials and Methods}

\section{Experimental details and agronomic management}

A field experiment was conducted at Regional Agricultural Research Station, Professor Jayashankar Telangana State Agricultural University, Palem, Southern Telangana Zone, Telangana state, India during kharif season of 2013 and 2014 under rainfed conditions. The soil of experimental site was Alfisol with a $\mathrm{pH}$ of 6.84 , EC of $0.14 \mathrm{dSm}^{-1}$, low in available nitrogen and high in available phosphorus and potassium. Six varieties viz., HG-365, HG563, RGC-936, RGC-1002, RGC-1035 and RGC-1066 were tested in a randomised block design with four replications. The characteristic features of varieties under test are furnished in Table 1. Seeds were dibbled at $45 \mathrm{~cm} \times 15 \mathrm{~cm}$ spacing on 7-8-2013 and 13-72014 during 2013 and 2014, respectively. A net plot size of $4.5 \mathrm{mx} 6.0 \mathrm{~m}\left(27.0 \mathrm{~m}^{2}\right)$ was maintained. A fertilizer dose of $20 \mathrm{~kg} \mathrm{~N}, 40 \mathrm{~kg}$ $\mathrm{P}_{2} \mathrm{O}_{5}$ and $30 \mathrm{~kg} \mathrm{~K}_{2} \mathrm{O} \mathrm{ha}^{-1}$ through urea, single super phosphate and muriate of potash was applied as basal. Besides, seed inoculation was done with Rhizobium biofertilizer as it is a non-traditional crop in the region. The crop was kept weed free by spraying a preemergence herbicide pendimethalin @ $0.75 \mathrm{~kg}$ a.i ha ${ }^{-1}$ followed by two hand weedings at 30 and 45 days after sowing. Harvesting was done by uprooting the plants from net plot of each treatment followed by drying in the sun for a week and then pods were threshed to get seed. Seed from each net plot treatment was weighed and converted into tonnes per hectare $\left(\mathrm{t} \mathrm{ha}^{-1}\right)$.

\section{Chemical analysis}

Initial soil available $\mathrm{N}, \mathrm{P}$, and $\mathrm{K}$ were estimated using alkaline permanganate method (Subbiah and Asija, 1956), Olsens' method (Olsen et al., 1954) and ammonium acetate method (Jackson, 1973), respectively. N, P and $\mathrm{K}$ content in the straw and seed samples were determined by micro-kjeldhal method (Piper, 1966), vanadomolybdo phosphoric yellow color method and flame photometer method (Jackson, 1973), respectively. Nutrient uptake by seed or straw was calculated as a function of nutrient content (\%) and grain or straw yield. The protein content in the seed was calculated by multiplying nitrogen concentration with a factor 6.25 (AOAC, 1960).

\section{Climate data}

Minimum temperature $\left(20\right.$ to $\left.22^{\circ} \mathrm{C}\right)$ was found to be low during $27^{\text {th }}$ to $43^{\text {rd }}$ standard meteorological weeks (SMW) and it was high (22 to $24^{\circ} \mathrm{C}$ ) during 34-36 (SMW) persisted. While during 2014, corresponding week wise minimum temperatures were slightly high (20 to $24^{\circ} \mathrm{C}$ ). $\mathrm{RH}$ (II) was also found to be high 
during cropping period during 2013 as compared to that of 2014. An amount of $374.89 \mathrm{~mm}$ rainfall was received during 27 to 38 SMW in 32 rainy days during 2013 against $363.4 \mathrm{~mm}$ in 31 days in 2014. On the otherhand, very high rainfall of $383.4 \mathrm{~mm}$ was received in 12 rainy days with high rainfall events of $152.8 \mathrm{~mm}$ during $41^{\text {st }} \mathrm{SMW}$ and $200.8 \mathrm{~mm}$ during $43^{\text {rd }}$ SMW during 2013 against only $58 \mathrm{~mm}$ rainfall in 6 days during 2014. Besides, low evaporation rates were observed throughout cropping season during 2013 vis-a-vis 2014.

\section{Statistical analysis}

The data on all growth and yield traits, yield, quality and nutrient uptake were analyzed by using F-test as per the procedure given by Gomez and Gomez (1984). The estimates of PCV and GCV were classified as low (< $10 \%)$, medium (10-20\%), and high (> 20\%) and heritability estimates (broad-sense) for yield components were done following Singh and Chaudhary (1985). Genetic advance was estimated and categorised as > 20\% = high; $10-20 \%=$ moderate; less than $10 \%=$ low as per the method given by Johnson et al., (1955). The genotypic and phenotypic correlation coefficients were calculated using the method of Al-Jibouri et al., (1958). The cause and effect relationships were estimated as per the procedure given by Dewey and Lu (1959).

\section{Results and Discussion}

\section{Agronomic evaluation of guar varieties}

Agronomic evaluation revealed that significant variation existed among varieties for different morphological and yield traits studied (Table 2). RGC-1066, a non-branching variety with significantly less no. of pods (39.8) and clusters plant ${ }^{-1}$ (8.8) grew significantly taller $(142.5 \mathrm{~cm})$ than all other varieties. On the contrary, RGC-936 variety has produced significantly more no. of branches (6.6), pods (51.2) and clusters plant ${ }^{-1}$ (18.9), however, it was at par with that of RGC-1035, HG-563, RGC-1002 and HG-365 for branches and pods; RGC-1035 and HG365 for clusters plant ${ }^{-1}$. While, 1000 seed weight of all six varieties was statistically similar.

Regardless of year of experimentation, RGC936 has produced significantly higher seed yield $\left(0.70\right.$ and $\left.1.141 \mathrm{t} \mathrm{ha}^{-1}\right)$. Pooled data showed that RGC-936 (0.920 $\left.\mathrm{t} \mathrm{ha}^{-1}\right)$ being at with HG-365 (0.739 $\left.\mathrm{t} \mathrm{ha}^{-1}\right)$ has significantly out yielded rest of the four varieties viz., HG563 (0.727 $\left.\mathrm{t} \mathrm{ha}^{-1}\right)$, RGC-1002 (0.678 $\left.\mathrm{t} \mathrm{ha}^{-1}\right)$ and RGC-1066 (0.490 t ha $\left.{ }^{-1}\right)$. Further, RGC$936\left(3.095 \mathrm{t} \mathrm{ha}^{-1}\right)$ produced significantly more biological yield than other varieties barring RGC-1002 (2.921 t ha $\left.{ }^{-1}\right)$, RGC-1035 (2.850 t $\mathrm{ha}^{-1}$ ) and HG-365 (2.807 t ha $\left.{ }^{-1}\right)$. The variety HG-563 (30.2) stood first in recording significantly higher harvest index and is followed by RGC-936 (29.3). The outstanding performance of guar variety RGC-936 could be attributed to highest number of branches, pods and clusters plant ${ }^{-1}$ than other varieties (Table 3 ). It means the variety has very good adaptation capacity to the semi-arid environment.

Different varieties differed in their ability in mining nutrients from the soil. Among all varieties under test, RGC-936 variety has removed significantly higher quantity of $\mathrm{N}$ (152.8 $\mathrm{kg} \mathrm{ha}^{-1}$ ) and $\mathrm{P}\left(14.3 \mathrm{~kg} \mathrm{ha}^{-1}\right)$ barring RGC-1002 and RGC-1035 in case of $\mathrm{N}$ and RGC-1002, RGC-1035 and HG-365 for P. Potassium uptake by different varieties followed similar trend as that of N.. Though more protein content $(31.2 \%)$ was observed with RGC-1002, significantly higher protein yield $\left(0.284 \mathrm{t} \mathrm{ha}^{-1}\right)$ was recorded with RGC936 having $30.8 \%$ protein content (Table 3 ). Economic analysis showed that, higher gross 
(Rs. $46508 \mathrm{ha}^{-1}$ ) and net (Rs. $31758 \mathrm{ha}^{-1}$ ) returns besides highest $\mathrm{B}$ : $\mathrm{C}$ ratio (3.15) were accrued with RGC-936 variety (Table 3). Earlier, Meena (2014) reported significantly higher NPK uptake, net returns and B: $\mathrm{C}$ ratio in RGC-1025 variety among the varieties under test. Review of published work internationally revealed that, of the four varieties viz., Esser, Kinman, Lewis and Santa Cruz tested in a Mediterranean environment in South Italy, Lewis and Santa Cruz were found to be most productive ones (Gresta et al., 2013) due to tallness, more dry matter production and 1000 seed weight besides longer duration. Among three varieties viz., 2/1, Mills and Brooks varieties studies in Bahawalpur, Pakistan, the variety " $2 / 1$ " with more no. of branches and pods and 1000 seed weight, has significantly outyielded the other two varieties (Mahmood et al., 1988). Literature in India over the years inferred that guar variety RGC-986 produced significantly more number of yield attributing characters thus higher grain yield than RGC 1003, RGC1017 and RGC- 936 varieties (Choudhary et al., 2006). The variety RGC-197 produced significantly higher seed yield than RGC-936 and RGC-986 (Sharma and Nehara, 2004).

Choudhary et al., (2004) found that out of 28 genotypes, the highest average seed yield was recorded with RGC-1012. A variety RGM-112 gave significantly higher mean seed yield as against the check RGC 936 and HGS 365 in the co-ordinated experiments (Bhansali and Bhandri, 2004). Thus, most of the literature shows that it is the inherent ability of a variety to produce better morphological and yield attributes thus seed yield.

\section{Genetic analysis of guar varieties}

The extent of variability for any character is very important for the improvement of a crop through breeding. The variability of the characters is measured by mean, range, Genotypic Coefficient of Variation (GCV), Phenotypic Coefficient of Variation (PCV), Heritability $\left(h^{2} b\right)$, Genetic Advance (GA) and GA as percentage of mean. In the present study, the variability in the characters were assessed using all these statistics and are presented in Table 4. Good amount of variation was observed for all the traits except for harvest index. All the traits expressed high phenotypic and genotypic variances except for branches plant ${ }^{-1}, 1000$ seed weight and harvest index. PCV and GCV were lower for 1000 seed weight. PCV was higher than GCV for all the traits studied indicating the presence of environmental influence on the expression of these traits. Majumder et al., (2008) reported similar result in case of spring wheat. Heritability was high for plant height and branches plant ${ }^{-1}$. The result is in agreement with Sultan et al., (2012) who reported similar results in guar. Low heritability value was observed for 1000 seed weight indicating that this character had more of environmental influence. Similar such observations were earlier made in guar by Morris (2010) and Manivannan et al., (2015).

Table.1 Characteristic features of guar varieties used in the experiment

\begin{tabular}{|l|l|l|}
\hline S. No. & \multicolumn{1}{|c|}{ Variety } & \multicolumn{1}{c}{ Characteristic features } \\
\hline $\mathbf{1}$ & HG-365 & Late (110-120 days) maturing and branching variety \\
\hline $\mathbf{2}$ & HG-563 & Late (110-120 days) maturing and branching variety \\
\hline $\mathbf{3}$ & RGC-936 & Early (85-100 days) maturing and branching variety with pinkish seed \\
\hline $\mathbf{4}$ & RGC-1002 & Early (85-100 days) maturing and branching variety \\
\hline $\mathbf{5}$ & RGC-1035 & Early (85-100 days) maturing and branching variety \\
\hline $\mathbf{6}$ & RGC-1066 & Early (85-100 days) maturing and single stem/unbranched variety \\
\hline
\end{tabular}


Table.2 Variation in growth, yield traits, yield and nutrient uptake among different varieties of guar (Pooled data of 2013 and 2014)

\begin{tabular}{|c|c|c|c|c|c|c|c|c|c|c|c|c|c|}
\hline \multirow[t]{2}{*}{ Varieties } & \multirow{2}{*}{$\begin{array}{l}\text { Plant } \\
\text { height } \\
(\mathrm{cm})\end{array}$} & \multirow{2}{*}{$\begin{array}{c}\text { No. of } \\
\text { branches } \\
\text { plant }^{-1}\end{array}$} & \multirow{2}{*}{$\begin{array}{l}\text { No. of } \\
\text { pods } \\
\text { plant }^{-1}\end{array}$} & \multirow{2}{*}{$\begin{array}{l}\text { No. of } \\
\text { clusters }^{-1} \\
\text { plant }^{-1}\end{array}$} & \multirow{2}{*}{$\begin{array}{c}1000 \text { seed } \\
\text { weight } \\
(\mathrm{g})\end{array}$} & \multicolumn{3}{|c|}{ Seed yield $\left(\mathrm{t} \mathrm{ha} \mathrm{a}^{-1}\right)$} & \multirow{2}{*}{$\begin{array}{c}\text { Protein } \\
\text { content } \\
(\%)\end{array}$} & \multirow{2}{*}{$\begin{array}{c}\text { Protein } \\
\text { yield } \\
\left(\mathbf{t ~ h a}^{-1}\right)\end{array}$} & \multirow{2}{*}{$\begin{array}{c}\text { N uptake } \\
(\mathbf{k g} \\
\left.\text { ha }^{-1}\right)\end{array}$} & \multirow{2}{*}{$\begin{array}{c}\text { P uptake } \\
(\mathrm{kg} \\
\left.\mathrm{ha}^{-1}\right)\end{array}$} & \multirow{2}{*}{$\begin{array}{c}\text { K uptake } \\
(\mathrm{kg} \\
\left.\text { ha }^{-1}\right)\end{array}$} \\
\hline & & & & & & 2013 & 2014 & Pooled & & & & & \\
\hline HG 365 & 62.0 & 6.3 & 49.5 & 15.6 & 32.2 & 0.548 & 0.931 & 0.739 & 28.4 & 0.210 & 127.3 & 12.5 & 64.4 \\
\hline HG 563 & 59.2 & 5.3 & 44.0 & 14.2 & 31.6 & 0.608 & 0.847 & 0.727 & 29.6 & 0.214 & 115.5 & 10.6 & 58.5 \\
\hline RGC 936 & 67.1 & 6.6 & 51.2 & 18.9 & 32.3 & 0.700 & 1.141 & 0.920 & 30.9 & 0.284 & 152.8 & 14.3 & 73.3 \\
\hline RGC 1002 & 59.1 & 6.1 & 47.0 & 13.4 & 32.2 & 0.545 & 0.812 & 0.678 & 31.2 & 0.212 & 146.2 & 14.2 & 65.8 \\
\hline RGC 1035 & 68.4 & 5.0 & 49.8 & 17.7 & 31.6 & 0.423 & 0.853 & 0.638 & 30.8 & 0.196 & 140.5 & 13.6 & 63.8 \\
\hline RGC 1066 & 142.5 & 0.0 & 39.8 & 8.8 & 32.1 & 0.339 & 0.641 & 0.490 & 26.6 & 0.130 & 108.8 & 10.6 & 59.9 \\
\hline SEm \pm & 3.30 & 0.4 & 3.3 & 1.32 & 0.4 & 0.080 & 0.091 & 0.057 & 0.5 & 0.016 & 4.8 & 0.8 & 3.5 \\
\hline LSD (0.05) & 10.0 & 1.3 & 10.0 & 4.0 & 1.3 & 0.241 & 0.275 & 0.137 & 1.4 & 0.047 & 14.6 & 2.5 & NS \\
\hline CV (\%) & 8.7 & 18.1 & 14.1 & 17.9 & 2.7 & 30 & 21 & 17 & 3.1 & 15.0 & 7.3 & 13.1 & 10.9 \\
\hline
\end{tabular}

LSD: Least Significant Difference SEm \pm : Standard Error of Mean CV: Co-efficient of Variation

Table.3 Variation in biological yield, harvest index and economics of guar varieties

\begin{tabular}{|c|c|c|c|c|c|c|c|c|c|c|}
\hline \multirow[t]{3}{*}{ Varieties } & \multirow{2}{*}{\multicolumn{3}{|c|}{$\begin{array}{l}\text { Biomass yield } \\
\left(\mathrm{t} \mathrm{ha}^{-1}\right)\end{array}$}} & \multirow{2}{*}{\multicolumn{3}{|c|}{$\begin{array}{l}\text { Biological yield } \\
\qquad\left(\mathrm{t} \mathrm{ha}^{-1}\right)\end{array}$}} & \multicolumn{4}{|c|}{ Pooled data of two years 2013 and 2014} \\
\hline & & & & & & & \multirow{2}{*}{ HI (\%) } & \multirow{2}{*}{$\begin{array}{l}\text { Gross returns } \\
\quad\left(\operatorname{Rs~ha}^{-1}\right)\end{array}$} & \multirow{2}{*}{$\begin{array}{l}\text { Net returns } \\
\left(\operatorname{Rs~ha}^{-1}\right)\end{array}$} & \multirow{2}{*}{$\begin{array}{l}\text { B:C } \\
\text { ratio }\end{array}$} \\
\hline & 2013 & 2014 & Pooled & 2013 & 2014 & Pooled & & & & \\
\hline HG 365 & 1.761 & 2.375 & 2.068 & 2.308 & 3.306 & 2.807 & 25.5 & 37358 & 22608 & 2.53 \\
\hline HG 563 & 1.330 & 2.103 & 1.716 & 1.938 & 2.949 & 2.443 & 30.2 & 36751 & 22001 & 2.49 \\
\hline RGC 936 & 1.927 & 2.422 & 2.175 & 2.627 & 3.563 & 3.095 & 29.3 & 46508 & 31758 & 3.15 \\
\hline RGC 1002 & 2.132 & 2.353 & 2.242 & 2.676 & 3.165 & 2.921 & 23.1 & 34274 & 19524 & 2.32 \\
\hline RGC 1035 & 2.065 & 2.360 & 2.213 & 2.488 & 3.213 & 2.850 & 22.2 & 32252 & 17502 & 2.19 \\
\hline RGC 1066 & 1.381 & 2.769 & 2.075 & 1.720 & 3.410 & 2.565 & 19.1 & 24770 & 10021 & 1.68 \\
\hline SEm \pm & 0.148 & 0.148 & 0.082 & 0.176 & 0.195 & 0.106 & 0.016 & & & \\
\hline LSD (0.05) & 0.445 & 0.446 & 0.247 & 0.532 & 0.587 & 0.319 & 0.049 & & & \\
\hline CV (\%) & 17 & 12 & 78 & 15 & 12 & 8 & 13.1 & & & \\
\hline
\end{tabular}

Market rate of guar seed: Rs. $50552 \mathrm{t}^{-1} \quad$ B: C ratio: Benefit: Cost ratio 
Table.4 Estimates of variance (genotypic, phenotypic, means, GCV, PCV, $\mathrm{h}^{2}$ and genetic advance of important quantitative traits of guar genotypes (Pooled data of 2013 and 2014)

\begin{tabular}{|c|c|c|c|c|c|c|c|c|c|}
\hline Character & $\begin{array}{l}\text { Plant } \\
\text { height } \\
\text { (cm) }\end{array}$ & $\begin{array}{l}\text { No. of } \\
\text { branches } \\
\text { plant }^{-1}\end{array}$ & $\begin{array}{l}\text { No. of } \\
\text { pods } \\
\text { plant }^{-1}\end{array}$ & $\begin{array}{l}\text { No. of } \\
\text { clusters } \\
\text { plant }^{-1}\end{array}$ & $\begin{array}{c}1000 \\
\text { seed } \\
\text { weight } \\
(\mathrm{g})\end{array}$ & $\begin{array}{c}\text { Seed yield } \\
\left(\mathrm{kg} \mathrm{ha}^{-1}\right)\end{array}$ & $\begin{array}{c}\text { Biomass } \\
\text { yield } \\
\left(\mathrm{kg} \mathrm{ha}^{-1}\right)\end{array}$ & $\begin{array}{l}\text { Biological } \\
\text { yield (kg ha } \\
\mathbf{1} \text { ) }\end{array}$ & $\begin{array}{l}\text { Harvest } \\
\text { index }\end{array}$ \\
\hline $\begin{array}{c}\text { Var } \\
\text { Environmental } \\
\end{array}$ & 48.41 & 1.07 & 32.78 & 13.67 & 0.01 & 10616.50 & 81185.18 & 164816.48 & 0.00 \\
\hline ECV & 9.04 & 21.16 & 12.22 & 25.06 & 2.60 & 14.74 & 13.69 & 14.60 & 19.87 \\
\hline $\begin{array}{c}\text { Var } \\
\text { Genotypical }\end{array}$ & 1041.30 & 5.95 & 14.26 & 11.13 & 0.00 & 18521.31 & 26942.35 & 36268.92 & 0.00 \\
\hline GCV & 41.94 & 49.96 & 8.06 & 22.61 & 0.48 & 19.47 & 7.89 & 6.85 & 15.89 \\
\hline $\begin{array}{c}\text { Var } \\
\text { Phenotypical }\end{array}$ & 1089.70 & 7.02 & 47.04 & 24.80 & 0.01 & 29137.81 & 108127.53 & 201085.41 & 0.00 \\
\hline PCV & 42.90 & 54.25 & 14.64 & 33.75 & 2.65 & 24.42 & 15.80 & 16.13 & 25.44 \\
\hline $\begin{array}{c}h^{2} \text { (Broad } \\
\text { Sense) }\end{array}$ & 0.96 & 0.85 & 0.30 & 0.45 & 0.03 & 0.64 & 0.25 & 0.18 & 0.39 \\
\hline $\begin{array}{c}\text { Genetic } \\
\text { Advancement } \\
5 \%\end{array}$ & 64.98 & 4.63 & 4.28 & 4.60 & 0.01 & 223.52 & 168.79 & 166.61 & 0.05 \\
\hline $\begin{array}{c}\text { Genetic } \\
\text { Advancement } \\
1 \%\end{array}$ & 83.28 & 5.93 & 5.49 & 5.90 & 0.01 & 286.45 & 216.31 & 213.52 & 0.07 \\
\hline $\begin{array}{c}\text { Gen. Adv as \% } \\
\text { of Mean } 5 \%\end{array}$ & 84.45 & 94.76 & 9.14 & 31.19 & 0.18 & 31.98 & 8.11 & 5.99 & 20.43 \\
\hline $\begin{array}{c}\text { Gen. Adv as \% } \\
\text { of Mean } 1 \%\end{array}$ & 108.23 & 121.44 & 11.72 & 39.98 & 0.23 & 40.98 & 10.39 & 7.68 & 26.19 \\
\hline General Mean & 76.94 & 4.88 & 46.85 & 14.75 & 3.20 & 698.94 & 2081.31 & 2780.25 & 0.25 \\
\hline Range lowest & 59.0688 & 0,0000 & 39.7813 & 8.8000 & 3.1550 & 490.2500 & 1716.1250 & 2443.3880 & 0.1900 \\
\hline Range highest & 142.5125 & 6.6313 & 51.1550 & 18.8875 & 3.2313 & 920.5000 & 2242.3750 & 3095.0480 & 0.3025 \\
\hline
\end{tabular}


Table.5 Phenotypic and genotypic coefficient of correlation among different traits of guar genotypes (Pooled data of 2013 and 2014)

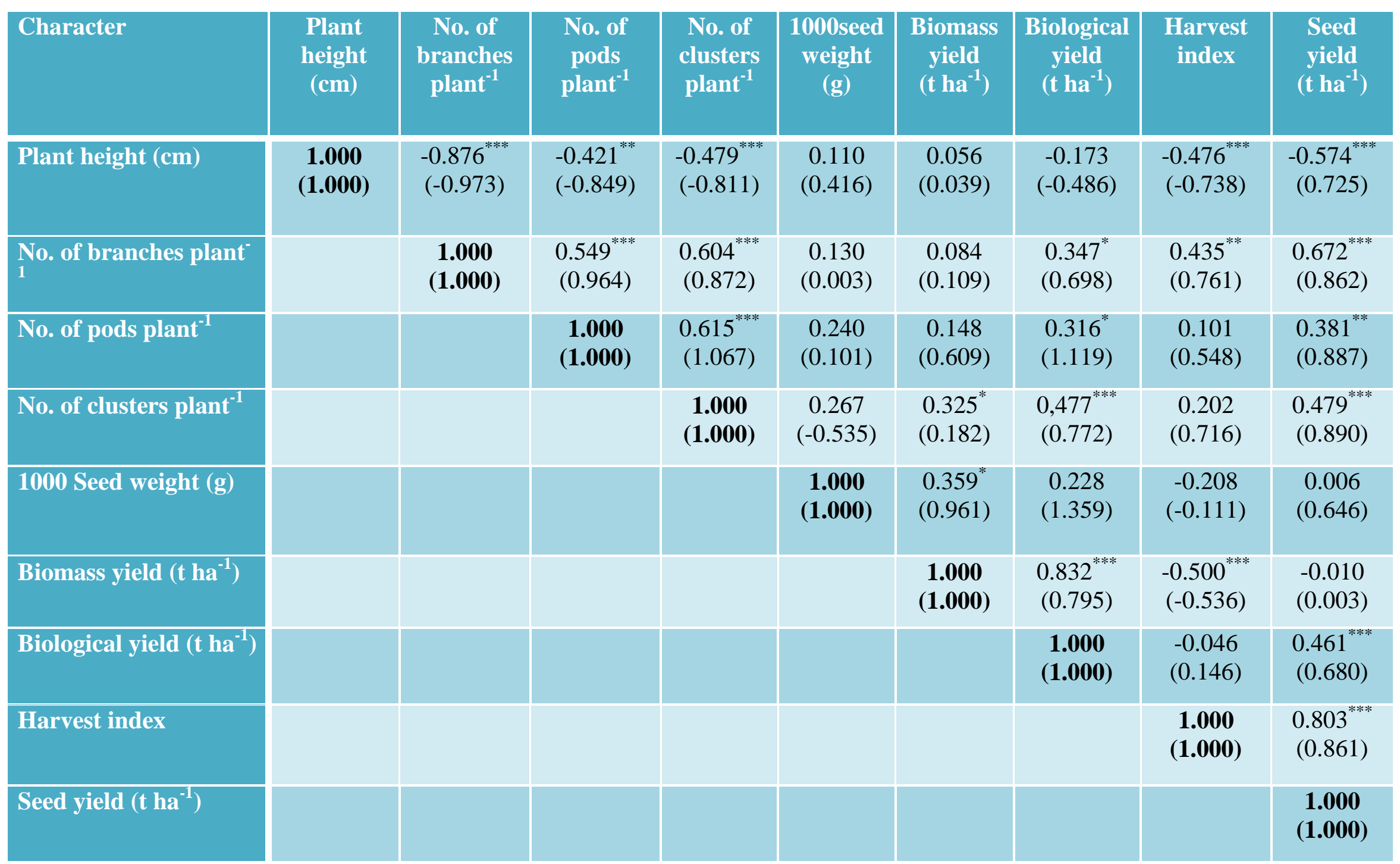

* Significant at $5 \%$ level; **Significant at $1 \%$ level; ***Significant at $0.5 \%$ level 
Table.6 Phenotypic path matrix of seed yield of guar genotypes (Pooled data of 2013 and 2014)

\begin{tabular}{|c|c|c|c|c|c|c|c|c|c|}
\hline Character & $\begin{array}{c}\text { Plant } \\
\text { height } \\
(\mathrm{cm})\end{array}$ & $\begin{array}{c}\text { No. of } \\
\text { branches } \\
\text { plant }^{-1}\end{array}$ & $\begin{array}{l}\text { No. of } \\
\text { pods } \\
\text { plant }^{-1}\end{array}$ & $\begin{array}{l}\text { No. of } \\
\text { clusters } \\
\text { plant }^{-1}\end{array}$ & $\begin{array}{l}\text { 1000seed } \\
\text { weight } \\
\text { (g) }\end{array}$ & $\begin{array}{l}\text { Seed } \\
\text { yield } \\
\left(\mathrm{t} \mathrm{ha}^{-1}\right)\end{array}$ & $\begin{array}{l}\text { Biomass } \\
\text { yield } \\
(\mathbf{t ~ h a - 1})\end{array}$ & $\begin{array}{c}\text { Biological } \\
\text { yield } \\
\left(\mathrm{t} \mathrm{ha}^{-1}\right)\end{array}$ & $\begin{array}{c}\text { Correlation } \\
\text { with seed } \\
\text { yield }\end{array}$ \\
\hline Plant height (cm) & 0.1057 & -0.0925 & -0.0445 & -0.0506 & 0.0117 & 0.0059 & -0.0182 & -0.0503 & $-0.574^{* * * *}$ \\
\hline No. of branches plant ${ }^{-1}$ & -0.2278 & 0.2601 & 0.1427 & 0.1572 & 0.0339 & 0.0218 & 0.0904 & 0.1132 & $0.672^{* * *}$ \\
\hline No. of pods plant-1 & -0.0396 & 0.0516 & 0.0941 & 0.0579 & 0.0226 & 0.0139 & 0.0297 & 0.0095 & $0.381^{* *}$ \\
\hline No. of clusters plant ${ }^{-1}$ & 0.0176 & -0.0223 & -0.0226 & -0.0368 & -0.0098 & -0.0126 & -0.0176 & -0.0075 & $0.479^{* * *}$ \\
\hline 1000 seed Weight $(\mathrm{g})$ & 0.0017 & 0.0020 & 0.0037 & 0.0042 & 0.0156 & 0.0056 & 0.0036 & -0.0033 & 0.006 \\
\hline Biomass yield $\left(\mathrm{t} \mathrm{ha}^{-1}\right)$ & -0.0022 & -0.0034 & -0.0060 & -0.0138 & -0.0144 & -0.0403 & -0.0335 & 0.0201 & -0.010 \\
\hline Biological yield $\left(\mathrm{t} \mathrm{ha}^{-1}\right)$ & -0.0762 & 0.1533 & 0.1394 & 0.2106 & 0.1004 & 0.3671 & 0.4414 & -0.0204 & $0.461^{* * * *}$ \\
\hline Harvest index & -0.3534 & 0.3227 & 0.0745 & 0.1501 & -0.1544 & -0.3711 & -0.0343 & 0.7417 & $0.803^{* * *}$ \\
\hline Partial $\mathbf{R}^{2}$ & -0.0607 & 0.1747 & 0.0359 & -0.0176 & 0.0001 & 0.0004 & 0.2036 & 0.5956 & \\
\hline
\end{tabular}

$\mathrm{R}^{2}=1.0363$ Residual effect $=$ SQRT $(1-1.0363)$

Diagonal bold values indicate direct effects

Fig.1 Diagrammatic representation of direct effects and correlation coefficients of variable on dependent variables of guar genotypes (Pooled data of 2013 and 2014)

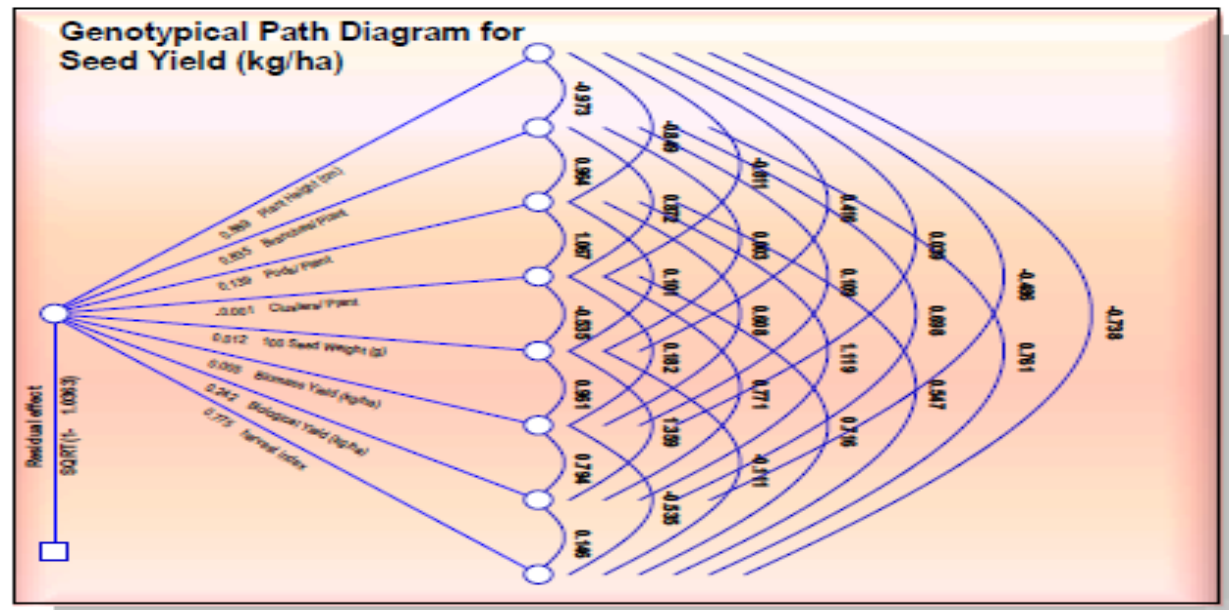

2802 
Heritability estimates along with genetic advance will be more useful in predicting the effect for selecting the best individual. The analysis of GA as percentage of mean was high for the characters such as plant height, seed yield, biomass yield and biological yield indicating selection based on these traits yield good results.

It is desirable for a plant breeder to know the extent of relationship between the yield and its various components which will facilitate the breeder in selecting plants of desirable characteristics. The phenotypic and genotypic correlation coefficients studied for all the traits are presented in Table 5. For majority of the traits, the genotypic correlation coefficients were higher than the phenotypic correlation coefficients. These results suggest that number of clusters plant ${ }^{-1}$, pods plant ${ }^{-1}$ and branches plant ${ }^{-1}$ and harvest index had high phenotypic and genotypic correlation coefficients with yield. Pods plant ${ }^{-1}$ had high positive correlation with biological yield and clusters plant $^{-1}$. The correlation of pods and clusters plant ${ }^{-1}$ with branches plant ${ }^{-1}$ was highly significant and positive. 1000 seed weight had recorded significant and positive correlation with biological yield, but, it had very low heritability and genetic advance. On the otherhand, plant height had negative correlation with yield attributes and yield. Furthermore, harvest index is negatively correlated with plant height, 1000 seed weight and biomass yield. Singh et al., (2004), Vir and Singh (2015), Saini et al., (2010) and Manivannan et al., (2015) have reported similar relationships among yield components and with yield itself in guar. This suggests that, in guar, genotypes with short height but with more number of branches plant ${ }^{-1}$ produce higher yield.

Path coefficients have been used in several crop species to provide information on interrelationships of complex characters and also to develop selection criteria. The relationship between yield and yield components may be positive or negative but it is the net result of direct effects of that particular trait and indirect effects through other traits. Hence, it is necessary to determine the path coefficients which position the observed correlation into direct and indirect effects and also reveals the cause and effect relationships between yield and their related traits.

The genotypic path matrix of seed yield indicated high positive direct effect of biological yield (0.7417) and biomass yield (0.4414) on seed yield (Table 6; Fig.1). However, branches plant ${ }^{-1}$, clusters plant ${ }^{-1}$ and pods plant $^{-1}$ had correlated indirectly to the seed yield.

Harvest index contributed maximum indirect effects to this trait. Crippa et al., (2009) reported similar finding in lentil. In guar, it is observed that the improvement for the yield could be achieved by applying selection pressure through indirect selection of pods plant $^{-1}$, clusters plant ${ }^{-1}$ and branches plant ${ }^{-1}$. Sheela et al., (2014) reported that pods plant ${ }^{-1}$ was the primary selection factor in their studies aimed at increasing yield in guar.

Results of our two year study clearly indicated that the variety RGC-936 is found agronomically and genetically superior as it produced higher yield traits such as branches, pods and clusters plant ${ }^{-1}$ thus seed and biological yield. Furthermore, all the traits under study expressed high GCV indicating good selection response.

Though, high heritability coupled with genetic advance was observed for traits such as plant height, seed and biomass yield, there was a negative correlation between seed yield and plant height. Hence, plant breeders have to design breeding programmes based on no. 
of pods, clusters and branches plant ${ }^{-1}$ which have positive association and direct contribution to yield in guar.

\section{References}

Al-Jibouri, H.A., Miller, P.A., and Robinson, H.F. 1958. Genotypic and environmental variance in an upland cotton cross of interspecific origin. Agron. J., 50: 633637.

AOAC 1960. Official method of analysis, Edn. 18, Association of Official Agricultural Chemists, Washington.

Ashraf, M.Y., Akhtar, K., Sarwar, G., and Ashraf, M. (2005). Role of the rooting system in salt tolerance potential of different guar accessions. Agron. Sustain. Dev., 25: 243-249.

Bhansali, A.K., and Bhandri, M.M. 2004. New clusterbean variety for arid and semi-arid tract of the country. National Symposium on Arid Legumes for Sustainable Agriculture and Trade, 5-7 $7^{\text {th }}$ Nov. pp. 131.

Choudhary, A.K., and Majumdar, V.L., and Shekhawat 2004. Evaluation of clusterbean genotypes for cultivation in summer season. National Symposium on Arid Legumes for Sustainable Agriculture and Trade, $5-7^{\text {th }}$ Nov. pp. 52.

Choudhary, R.N., Sharma, O.P., and Choudhary, R.S. 2006. Effect of varieties and levels of sulphur on growth and yield of guar. Ind. J. Fert., 2(7): 45 -47.

Crippa, I., Bermejo, C., Esposito, M.A., Martin, E.A., Cravero, V., Libaratti, D., Lopez Anido. F.S., and Cointry, E.L. 2009. Genetic variability, correlation and path analyses for agronomic traits in lentil genotypes. Intl. J. Pl. Breed., 3(2): 76-80.

Dewey, D.R., and Lu, K.H. 1959. A correlation and path coefficient analysis of components of crested wheat grass seed production. Agron. J. 51: 515-518.

Elsheikh, E.A.E., and Ibrahim, K.A. 1999. The effect of Bradyrhizobium inoculation on yield and seed quality of guar (Cyamopsis tetragonoloba L.). Food Chem., 65: 183187.

Francois, L.E., Donovan, T.J., and Maas, E.V. 1990. Salinity effects on emergence, vegetative growth and seed yield of guar. Agron. J., 82: 587-592.

Girish, M.H., Gasti, V.D., Thammaiah, N., Kerutagi, M.G., Mulge, R., Shantappa, T., and Mastiholi, A.B. 2012. Genetic divergence studies in guar genotypes (Cyamopsis tetragonoloba (L.) Taub.). Karnataka J. Agric. Sci., 25(2): 245-247.

Gomez, K.A., and Gomez, A.A. 1984. Statistical Procedures for Agricultural Research. Edn. 2, John Wiley and Sons, New York.

Gresta, F., Sortino, O., Carmelo, S., Luca I., Cristina, F., and Yves, M.G. 2013. Effects of sowing times on seed yield, protein and galactomannan content of four varieties of guar in a Mediterranean environment. Ind. Crops Prod., 41: 46-52.

Jackson, M.L. 1973. Soil chemical analysis. Prentice hall of India Pvt ltd., New Delhi.

Losavio, N., Infantino, A., and Vonella, V. 1995. Guar: unapotenziale coltura industriale dell'area mediterranea. Informatore Agrario., 39: 41-43.

Majumder, D.A.N., Shamsuddin, A.K.M., Kabir, M.A., and Hussain, L. 2008. Genetic variability, correlated response and path analysis of yield and yield attributing traits in spring wheat. $J$. Bangladesh Agril. Univ., 692: 227-234.

Manivannan, A., Anandakumar, C.R., Ushakumari, R., and Dahiya, G.S. 2015. Genetic diversity of guar genotypes (Cyamopsis tetragonoloba (L.) Taub.) based on agro-morphological traits. Bangladesh J. Bot., 44(1): 59-65.

Meena, H.S. 2014. Performance of clusterbean varieties at varied crop geometry. M.Sc. (Ag.) thesis submitted to Acharya N.G. Ranga Agricultural University, Hyderabad 500030.

Mohammad, A., Iqbal, M.A.M., and Saleem, M.I. 1988. Growth and yield of three guar cultivars as influenced by row spacings. Pak. J. Agric. Sci., 9(2): 168-170. 
Morris, J.B. 2010. Morphological and reproductive characterization of guar (Cyamopsis tetragonoloba) genetic resources regenerated in Georgia, USA. Genet. Resour. Crop Evol., 57: 985-993.

Olsen, S.R., Cole, C.W., Watanabe, F.S., and Dean, L.A. 1954. Estimation of available $P$ in soils by extraction with sodium bicarbonate. USDA circular No. 439.

Piper, C.S. 1966. Soil and plant analysis. Academic Press, New York. 368.

Ramanjaneyulu, A., Madhavi, A., Neelima, T.L., Naresh, P., Indudhar Reddy, K., and Srinivas, A. 2016. Effect of row spacing and sowing time on seed yield, quality parameters and nutrient uptake of guar [Cyamopsis tetragonoloba (L.) Taub] in semi arid climate of Southern Telanagana, India. Leg. Res., 41(2): 287-292. DOI: 10.18805/lr.v0i0.7599.

Saini, D.D., Singh, N.P., Chaudhary, S.P.S., Chaudhary, O.P., and Khedar, O.P. 2010. Genetic variability and association of component characters for seed yield in guar (Cyamopsis tetragonoloba L. Taub). J. Arid Leg., 7(1): 47-51.

Sharma, S.K., and Nehara, K.C. 2004. Effect of different varieties and fertilizer levels on yield and yield attributing characters of guar (Cyamopsis tetragonoloba (L.) Taub.). National Symposium on Arid Legumes for Sustainable Agriculture and Trade, 5- $7^{\text {th }}$ Nov. 2004. pp. 51.

Sharma, S.R. 1984. Effect of different cropping seasons and tridemorph sprays on powdery mildew and yield of guar. Zeitschrift für Acker-und Pflanzenbau 153(2): 81-89.
Sheela, N.M., Madalageri, M.B., and Kotikal, Y.K. 2014. Correlation and path analysis in clusterbean (Cyamopsis tetragonoloba (L.) Taub.) for vegetable pod yield and its component characters. The Bio. 9(4): 1609-1612.

Singh, A., Jat, N.L., Raghavendra, S., and Pal, S. 2014. Effect of fertility levels and bioinoculants on productivity, profitability, quality and nutrient acquisition of guar (Cyamopsis tetragonoloba). Ind. J. Agron., 59(3): 485-488.

Singh, J.V., Chander, S., and Sharma, S. 2004. Correlation and path coefficient analysis in clusterbean (Cyamopsis tetragonoloba (L.) Taub.). Plant Improv., 6(2): 128-129.

Singh, R.K., and Chaudhary, B.D. 1985. Biometrical methods in quantitative genetic analysis. Kalyani Publishers, New Delhi, p. 318.

Subbaiah, B.V., and Asija, G.L. 1956. A rapid procedure for the determination of available nitrogen in soils. Cur. Sci., 25: 259-260.

Sultan, M., Yousuf, M.N., Rabbani, M.A., Shinwari, Z.K., and Masood, M.S. 2012. Phenotypic divergence in guar (Cyamopsis tetragonoloba L.) landrace genotypes of Pakistan. Pak. J. Bot., 44: 203-210.

Vir, O., and Singh, A.K. 2015. Variability and correlation analysis in the clusterbean (Cyamopsis tetragonoloba (L.) Taub.) in hyper hot arid climate of Western India. Leg. Res. 38(1): 37-42.

\section{How to cite this article:}

Ramanjaneyulu, A.V., A. Madhavi, M. Venkata Ramana, T.L. Neelima, K. Indudhar Reddy, A. Srinivas, G. Anuradha and Sameer Kumar, C.V. 2018. Agronomic and Genetic Analysis of Performance of Guar Varieties under Rainfed Conditions in a Semi-Arid Climate on Alfisols. Int.J.Curr.Microbiol.App.Sci. 7(08): 2795-2805. doi: https://doi.org/10.20546/ijcmas.2018.708.294 